\title{
Comparative study on the composition of four different varieties of garlic
}

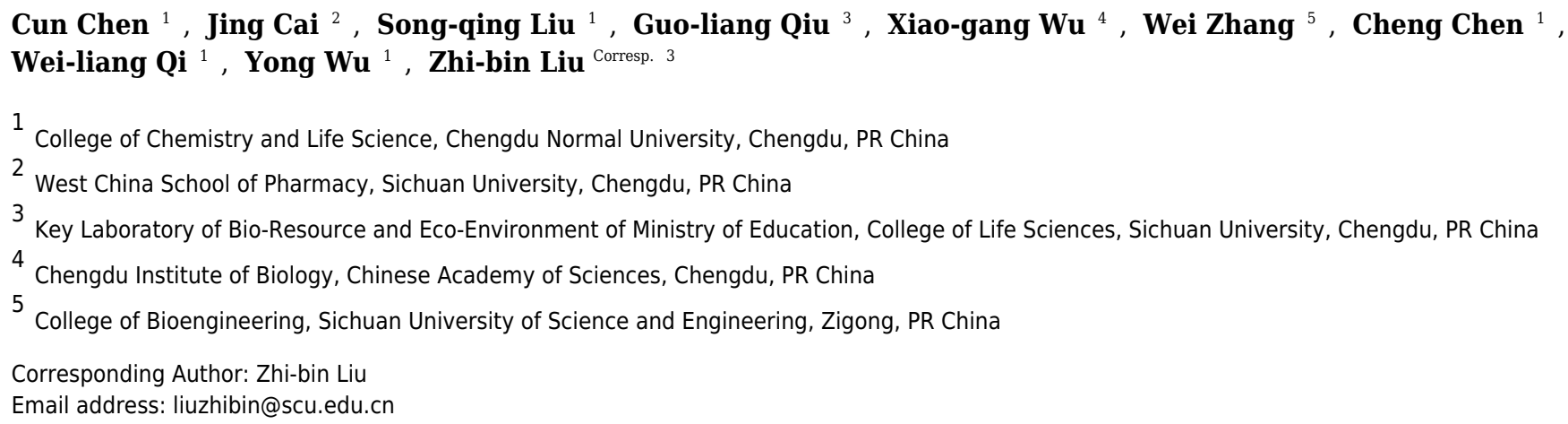

Garlic is used as a medicinal seasoning worldwide. The aim of this work was to compare four varieties of garlic: 'Taicangbaipi', 'Ershuizao', 'Hongqixing', and 'Single-clove', among them, 'Ershuizao' and 'Hongqixing' are unique to Sichuan Province of China. Firstly, soluble sugar, starch, and the protein content of the garlic were analyzed. There was more soluble sugar in 'Single-clove', total starch in 'Hongqixing', and protein content in 'Ershuizao' relative to the other three varieties, respectively. Gas chromatography-mass spectrometry (GC-MS) analysis showed that 'Ershuizao' and 'Hongqixing' contained high levels of 5Hydroxymethylfurfural, which has antitumor, antioxidant, and cytoprotective effects. Indeed, the extracts from these two types of garlic were more effective at inhibiting tumor growth than that from the others. Moreover, the sulfide content and antimicrobial effects of 'Ershuizao' and 'Hongqixing' garlic were also higher than those of the other two types of garlic. In addition, changes observed in the membrane permeability and protein leakage suggest that the antimicrobial activity of the 'Ershuizao' and 'Hongqixing' extracts may be due to the destruction of the structural integrity of the cell membranes, leading to cell death. 
1 Comparative Study on the Composition of Four Different Varieties of Garlic

2 Cun Chen ${ }^{1}$, Jing Cai ${ }^{2}$, Song-qing Liu ${ }^{1}$, Guo-liang Qiu ${ }^{3}$, Xiao-gang Wu ${ }^{4}$, Wei Zhang ${ }^{5}$, Cheng

3 Chen ${ }^{1}$, Wei-liang Qi ${ }^{1}$, Yong Wu${ }^{1}$, Zhi-bin Liu ${ }^{3 *}$,

41 College of Chemistry and Life Science, Chengdu Normal University, Chengdu 611130, Sichuan, PR China

52 West China School of Pharmacy, Sichuan University, Chengdu 610064, Sichuan, PR China

63 Key Laboratory of Bio-Resource and Eco-Environment of Ministry of Education, College of Life Sciences,

7 Sichuan University, Chengdu 610064, Sichuan, PR China

84 Chengdu Institute of Biology, Chinese Academy of Sciences, Chengdu 610064, Sichuan, PR China

95 College of Bioengineering, Sichuan University of Science \& Engineering, Zigong 643000, Sichuan, PR China

$10 *$ Corresponding author:

11 Zhi-bin $\mathrm{Liu}^{3}$

12 Key Laboratory of Bio-Resource and Eco-Environment of Ministry of Education, College of Life Sciences, Sichuan

13 University, Chengdu 610064, Sichuan, PR China. Tel: +86 02885412281

14 E-mail addresses : liuzhibin@scu.edu.cn

ABSTRACT:

Garlic is used as a medicinal seasoning worldwide. The aim of this work was to compare four varieties of garlic: ‘Taicangbaipi', 'Ershuizao', 'Hongqixing', and 'Single-clove', among them, 'Ershuizao' and 'Hongqixing' are unique to Sichuan Province of China. Firstly, soluble sugar, starch, and the protein content of the garlic were analyzed. There was more soluble sugar in 'Single-clove', total starch in 'Hongqixing', and protein content in 'Ershuizao' relative to the other three varieties, respectively. Gas chromatography-mass spectrometry (GC-MS) analysis showed that 'Ershuizao' and 'Hongqixing' contained high levels of 5-Hydroxymethylfurfural, which has antitumor, antioxidant, and cytoprotective effects. Indeed, the extracts from these two types of garlic were more effective at inhibiting tumor growth than that from the others. Moreover, the sulfide content and antimicrobial effects of 'Ershuizao' and 'Hongqixing' garlic were also higher than those of the other two types of garlic. In addition, changes observed in the membrane permeability and protein leakage suggest that the antimicrobial activity of the 'Ershuizao' and 'Hongqixing' extracts may be due to the destruction of the structural integrity of the cell membranes, leading to cell death.

\section{Introduction}

Quality is an important factor that is taken into account when people choose food. The quality of food includes appearance, texture, aroma, taste, nutritional value, chemical composition, and functional properties. Nowadays, consumers are becoming increasingly interested in health issues, and the quality of food has gradually become a major factor in purchasing decisions. Along with some functional ingredients such as antioxidants and antiaging substances, sugar, starch, and protein are the main nutrients that people consider when 
37 choosing foods. Different varieties, harvesting methods, and regions can lead to different levels 38 of quality and contents. It was reported that fruit quality, size and shape traits significantly differed among ten historic USA tomato varieties (Cho \& Kim 2008). Narváez-Cuenca found that macronutrient contents (protein, fat, soluble dietary fibre and insoluble dietary fibre) varied widely among 113 genotypes of potatoes (Park et al. 2010). Zheng found varying sugar levels in different varieties of Lycium barbarum and the congeneric species of Lycium chinense from different regions (Zheng et al. 2010). Monti found differing organoleptic and nutritional properties among different varieties of peach; these characteristics are related to their chemical composition (sugars and organic and amino acids) (Monti et al. 2016).

The Allium genus contains more than 600 different species that are widely distributed throughout Europe, North America, North Africa, and Asia (Ozturk et al. 2012). Most Allium species possess characteristic aromas and are edible. Garlic (Allium sativum) is consumed as a seasoning worldwide, and has been used for its important medicinal properties for centuries (Itakura et al. 2001; Martins et al. 2016; Matsutomo et al. 2018; Mukthamba \& Srinivasan 2015). Many components in garlic, including sulfur-free compounds, work together to provide various health benefits. A double-blind crossover study conducted in a group of 41 men with moderate hypercholesterolemia showed that dietary supplementation of old garlic extracts was beneficial to the lipid profile and blood pressure of patients with moderate hypercholesterolemia (Steiner et al. 1996). Hosono showed that a flavor component obtained from garlic, diallyl trisulfide (DATS), exhibits antitumor activity (Hosono et al. 2005). Moreover, Durak showed the antioxidative effects of garlic extract in 11 patients with atherosclerosis (Durak et al. 2004). Garlic is considered an alternative health food because of those effects of improving the immune system.

China ranks first among the world's garlic-producing countries, and garlic consumers in Sichuan Province of China have access to four varieties of garlic in the local agricultural market: 'Taicangbaipi', 'Ershuizao', 'Hongqixing', and 'Single-clove', among them, 'Ershuizao' and 'Hongqixing' are unique to Sichuan Province of China. The main objective of the present study was to analyze the nutritional value of these different types of garlic, and to compare the antimicrobial and antitumor effects of their extracts.

\section{Materials and methods}

\subsection{Materials and preparation}

Four different varieties of garlic were purchased from the local agricultural market; the garlic bulbs and peeled garlic cloves are shown in Fig. 1. 'Taicangbaipi' and 'Ershuizao' were purchased in supermarket of Chengdu, and 'Hongqixing' and 'Single-clove' were bought in local market of Wenjiang. The garlic bulbs were peeled and crushed.

\subsection{Determination of soluble sugar and starch}


Garlic juices $(0.3 \mathrm{~g})$ were extracted in $15 \mathrm{~mL}$ of $80 \%$ ethanol, and then centrifuged at 7000 rpm for $10 \mathrm{~min}$; the supernatant was retained for soluble sugar determination, whereas the precipitate was kept for starch extraction (Irigoyen et al. 1992). The precipitate was dissolved in $12 \mathrm{~mL}$ of $1.1 \% \mathrm{HCl}$ and thoroughly mixed. The solution was heated in a water bath at $100^{\circ} \mathrm{C}$ for $30 \mathrm{~min}$ to extract the starch, and after cooling, it was centrifuged at $7000 \mathrm{rpm}$ for $10 \mathrm{~min}$; the supernatant was retained and diluted to $50 \%$ solutions.

The total soluble sugar and starch were estimated using anthrone reagent (Sadasivam 1997). One milliliter of the diluted solutions were added to $5 \mathrm{~mL}$ of freshly prepared anthrone reagent ( $0.2 \mathrm{~g}$ anthrone was dissolved in $100 \mathrm{~mL}$ of $72 \%$ sulfuric acid), and the mixtures were heated in a boiling water bath for $10 \mathrm{~min}$. The tubes were removed and cooled, and then the absorbance of the content was measured at $625 \mathrm{~nm}$ in a spectrophotometer (Beijing Purkinje General Instrument Co., Ltd., China). The amount of total sugar present in the sample was calculated from a standard curve drawn from variable amounts of glucose and total starch obtained from a standard curve for potato starch.

\subsection{Determination of protein content}

Garlic juices ( $1 \mathrm{~g})$ were extracted in $3.5 \mathrm{~mL}$ protein extraction buffer containing $15 \%(\mathrm{v} / \mathrm{v})$ $1 \mathrm{M}$ Tris $-\mathrm{HCl}(\mathrm{pH} 8), 25 \%(\mathrm{v} / \mathrm{v})$ glycerol, and $2 \%(\mathrm{w} / \mathrm{v})$ polyvinylpyrrolidone. The mixture was kept on ice for $3 \mathrm{~h}$, and then centrifuged at 10,000 rpm for $20 \mathrm{~min}$ at $4^{\circ} \mathrm{C}$. Samples of each supernatant $(200 \mu \mathrm{L})$ were treated with $800 \mu \mathrm{L}$ Coomassie Brilliant Blue G-250. After 10 min, the mixtures were subjected to colorimetric analysis in a T6-spectrophotometer (Beijing Purkinje General Instrument Co., Ltd.) at $595 \mathrm{~nm}$. A standard curve was drawn using bovine serum albumin.

\subsection{GC-MS analysis}

Gas chromatography analyses were performed using a Shimadzu GC/MS-QP2010 system (Kyoto, Japan). A Rtx-Wax capillary column $(30 \mathrm{~m} \times 0.25 \mathrm{~mm}, 0.25 \mu \mathrm{m})$ was used, with helium carrier gas flowing at $1 \mathrm{~mL} / \mathrm{min}$; the column temperature was first kept at $60^{\circ} \mathrm{C}$ for $5 \mathrm{~min}$, then increased by $10^{\circ} \mathrm{C} / \mathrm{min}$ up to $280^{\circ} \mathrm{C}$. The injection port temperature was maintained at $220^{\circ} \mathrm{C}$. The MS data libraries NIST05.LIB and NIST05s.LIB were used for the spectrum analyses and compound identification.

\subsection{Microbial strains, culture, and antimicrobial test}

Xanthomonas campestris pv. malvacearum (BNCC138498), Pseudomonas syringae (BNCC134219), Fusarium proliferatum (BNCC143058), and Alternaria brassicicola (CICC264) were obtained from Beina Chuanglian Biological Research Institute (Beijing, China). The garlic juices were mixed with deionized water at $\mathrm{pH} 3.0$ at a ratio of $1: 2 \mathrm{~g} / \mathrm{mL}$ (Chen et al. 2017), for 2 hours at $4^{\circ} \mathrm{C}$.

Oxford cup assays were used in the antimicrobial experiments, with some modifications 
109 (Shang et al. 2014). Bacteria (X. campestris pv. malvacearum, P. syringae) were grown to an

110

111

112

113

114

115

116

117

118

119

120

121

122

123

124

125

126

127

128

129

130

131

132

133

134

135

136

137

138

139

140

141

142

143

144

$\mathrm{OD}_{600}$ of 0.6 in nutrition broth $(\mathrm{NB})$ at $28^{\circ} \mathrm{C}$ in a shaker, then $100 \mathrm{~mL}$ NB agar was mixed with 1 $\mathrm{mL}$ of the bacterial solutions and added to the plates. Fungi (F. proliferatum and A. brassicicola) were cultivated on potato dextrose agar (PDA) plates at $28^{\circ} \mathrm{C}$. The spores were washed with 10 $\mathrm{mL}$ of sterile water and centrifuged at $6000 \mathrm{rpm}$ for $5 \mathrm{~min}$ to remove the supernatant. The spores were then mixed with sterile water to a concentration of approximately $2 \times 10^{7} \mathrm{~mL}^{-1}$ as assessed by a hemocytometer. Then, $100 \mathrm{~mL}$ PDA agar was mixed with $0.5 \mathrm{~mL}$ spore suspension and added to the plates. Four Oxford cups (6-mm diameter) were placed above the agar surface, and $20 \mu \mathrm{L}$ garlic extract ('Taicangbaipi', 'Ershuizao', 'Hongqixing', and 'Single-clove') was added to each cup, respectively. The bacterial inhibition zones were observed after $24 \mathrm{~h}$ at $28^{\circ} \mathrm{C}$, and the fungal inhibition zones were observed after $2-4$ days at $28^{\circ} \mathrm{C}$. Three replicates were performed for each treatment.

\subsection{Cell membrane permeability}

After $24 \mathrm{~h}$ of incubation at $28^{\circ} \mathrm{C}, X$. campestris pv. malvacearum cells were treated with the extracts of the four garlic varieties. The culture samples $(5 \mathrm{~mL})$ were treated with $500 \mu \mathrm{L}$ of the garlic extracts, and the mixtures were incubated at $28^{\circ} \mathrm{C}$ for $1 \mathrm{~h}$ through to $12 \mathrm{~h}$, respectively. Conductance was recorded using a conductivity meter (DDS-307, SPSIC-Rex Instrument Factory, China) after incubation, and was expressed as the bacterial membrane permeability relative conductivity and measured according to the method of Diao (Diao et al. 2014).

\subsection{Integrity of cell membrane}

Bacterial cultures containing $500 \mu \mathrm{L}$ of the extracts of the four garlic varieties were centrifuged for $10 \mathrm{~min}$ at $6000 \mathrm{rpm}$, and the supernatants were obtained. The supernatants (200 $\mu \mathrm{L}$ ) were treated with $800 \mu \mathrm{L}$ Coomassie Brilliant Blue G-250, and the mixtures were analyzed at $595 \mathrm{~nm}$ on a T6-spectrophotometer (Beijing Purkinje General In-strument Co., Ltd, Beijing, China). The breakdown of bacterial cell membrane integrity manifested as protein leakage.

\subsection{Cytotoxic effects (antitumor) of the extracts of different garlic varieties on cells}

Cell Culture: Colorectal cancer (CRC) cells (SW480 and HCT116) were obtained from the American Type Culture Collection (Rockville, MD). The extracts of the four garlic varieties were dissolved in phosphate-buffered saline. The dilution ratios were $0,1 / 32,1 / 16,1 / 8,1 / 4$, and 1/2. SW480 and HCT116 cells were seeded in 96-well plates. Various concentrations of the garlic extracts were applied to the cells, and cell viability was analyzed after $72 \mathrm{~h}$ of incubation.

\section{Results}

\subsection{Soluble sugar, total starch, and protein content in different varieties of garlic}

As shown in Table 1, different varieties of garlic resulted in significantly different soluble sugar, total starch, and protein content. The highest soluble sugar content was observed in 'Single-clove', at a mean of $186.91 \mathrm{mg} / \mathrm{g}$. The mean starch levels of 'Hongqixing' and 
'Ershuizao' were $287.71 \mathrm{mg} / \mathrm{g}$ and $263.98 \mathrm{mg} / \mathrm{g}$, respectively, which were higher than that of both 'Taicangbaipi' and 'Single-clove'. It was also observed that 'Hongqixing' and 'Ershuizao' had higher protein contents, with mean levels of $45.23 \mathrm{mg} / \mathrm{g}$ and $51.04 \mathrm{mg} / \mathrm{g}$, respectively. However, the overall content of these parameters in the 'Taicangbaipi' extract was relatively lower than those in the other three extracts.

\subsection{Constituents by GC-MS analysis}

The identities of the compounds in the four varieties of garlic are listed in Table 2, and the GC-MS spectra of the constituents is shown in Fig. 2\&3. The most abundant constituent in the 'Taicangbaipi' extract was B-D-fructofuranosyl $\alpha$-D-glucopyranoside (27.34\%), followed successively by ethylic acid (22.40\%) and 2-amino-5-methylbenzoic acid (17.05\%). The main constituents of the 'Hongqixing' extract were B-D-fructofuranosyl $\alpha$-D-glucopyranoside (44.18\%) and 5-Hydroxymethylfurfural (26.78\%). The primary compounds in the 'Ershuizao' extract were 5-Hydroxymethylfurfural (47.10\%) and B-D-fructofuranosyl $\alpha$-D-glucopyranoside $(31.00 \%)$. Finally, the primary constituents of the 'Single-clove' extract were B-Dfructofuranosyl $\alpha$-D-glucopyranoside (61.07\%), 2-amino-5-methylbenzoic acid (9.07\%), and 5Hydroxymethylfurfural (4.88\%), in descending order.

\subsection{Activity of the extracts from different garlic varieties against plant pathogenic bacteria and fungi}

In order to determine the antimicrobial effects of the extracts of the different garlic varieties, two types of bacteria ( $X$. campestris pv. malvacearum, $P$. syringae) and two types of fungi ( $F$. proliferatum and A. brassicicola) were treated with the four garlic extracts. After incubation, the zones of inhibition showed that the 'Hongqixing' extract had the highest activity against the microorganisms, followed by 'Ershuizao', 'Taicangbaipi', and 'Single-clove', in descending order of activity. The experimental results are shown in Fig. 4.

\subsection{Changes in cell membrane permeability}

Membrane permeability experiments were performed to study the effect of the garlic extracts on bacterial cell membranes. Fig. 5A shows the effects of the extracts from the different garlic varieties on the membrane permeability of $X$. campestris pv. malvacearum. During the first $8 \mathrm{~h}$, there was almost no change in the relative conductivity of the control; however, an increase in the conductivity was observed at $12 \mathrm{~h}$, which may have been due to bacterial death. Similar to the control, the relative conductivity of the samples for 'Single-clove' and 'Taicangbaipi' were only slightly higher. However, compared to the control, with increasing treatment time and concentration of the 'Hongqixing' and 'Ershuizao' extracts, the conductivity increased rapidly. This meant that the permeability of the bacterial membrane would have increased correspondingly, resulting in the loss of intracellular components, especially $\mathrm{K}^{+}, \mathrm{Na}^{+}$, and other electrolytes. 
181

182

183

184

185

186

187

188

189

190

191

192

193

194

195

196

197

198

199

200

201

202

203

204

205

206

207

208

209

210

211

212

213

214

215

216

\subsection{Leakage of cellular contents}

Similar to the membrane permeability test, the extracts from the different garlic varieties elevated protein leakage through the plasma membrane of $X$. campestris pv. malvacearum (Fig. 5B). 'Single-clove' and 'Taicangbaipi' caused slight protein leakage, whereas 'Hongqixing' and 'Ershuizao' caused extensive protein leakage. These results indicate that the 'Hongqixing' and 'Ershuizao' extracts may cause irreversible damage to the bacterial plasma membrane, resulting in the loss of cellular components such as proteins and some essential molecules, leading to cell death.

\subsection{Analysis of cytotoxic (antitumor) effects}

After $72 \mathrm{~h}$ of incubation with extracts from different garlic varieties at different concentrations (dilution ratios of $0,1 / 32,1 / 16,1 / 8,1 / 4$, and 1/2), we analyzed the viability of SW480 (Fig. 6A) and HCT116 (Fig. 6B) cells. The cell viability for the control (no added garlic extract) was 100\%. After incubation with the extracts from the different varieties of garlic at different concentrations, the cell viability decreased by varying degrees. At $1 / 2$ concentration, after $72 \mathrm{~h}$, the SW480 cell viability was $21.18 \%$ when incubated with 'Ershuizao', 29.14\% with 'Hongqixing', 38.46\% with 'Single-clove', and 39.07\% with 'Taicangbaipi'. The extracts of 'Ershuizao' and 'Hongqixing' had strong cytotoxic effects on HCT116, with cell viabilities of $5.80 \%$ and $7.13 \%$, respectively. Conversely, the cell viability for HCT116 with 'Single-clove' was $40.76 \%$ and with 'Taicangbaipi' was $40.88 \%$.

\section{Discussion}

Four varieties of garlic are commercially available: 'Taicangbaipi', 'Ershuizao', 'Hongqixing', and 'Single-clove', and 'Ershuizao' and 'Hongqixing' are unique to Sichuan Province of China. In this study, we compared the components of the four garlic varieties, and found that the extracts of 'Hongqixing' and 'Ershuizao' exhibited significant antimicrobial and antitumor effects.

Table 1 shows the large variations in the levels of soluble sugar, total starch, and protein in the four varieties of garlic. Table 2 and Fig. $2 \& 3$ show that the constituents of the four garlic varieties also differed substantially. As shown in Table 2, 'Ershuizao' and 'Hongqixing' contained high levels of 5-Hydroxymethylfurfural, at $47.10 \%$ and $26.78 \%$, respectively. 5Hydroxymethylfurfural is a common product of the Maillard reaction, which occurs during heat processing and the preparation of many types of foods and beverages (Hwang et al. 2011; Molina-Calle et al. 2017). 5-Hydroxymethylfurfural is common in black garlic, which is prepared by heat treatment (Choi et al. 2014; Lu et al. 2017); however, there have been no reports of this compound in fresh garlic. Perez found that sucrose degrades into glucose and a very reactive fructofuranosyl cation under acidic conditions, and that this cation can be efficiently converted to 5-Hydroxymethylfurfural (Perez \& Yaylayan 2008). 5- 
217 Hydroxymethylfurfural has many beneficial effects that have become increasingly apparent, 218 including antitumor (Michail et al. 2007), antioxidant (Li et al. 2009), and cytoprotective (Ding 219 et al. 2010) effects. Fig. 6 show that both the 'Ershuizao' and 'Hongqixing' extracts, respectively,

220

221

222

223

224

225

226

227

228

229

230

231

232

233

234

235

236

237

238

239

240

241

242

243

244

245

246

247

248

249

250

251

252

exhibited significant cytotoxic effects on CRC cells (SW480 and HCT116). These results suggest that under acidic conditions ( $\mathrm{pH}$ 3.0), 'Ershuizao' and 'Hongqixing' garlic easily react and convert sucrose to 5-Hydroxymethylfurfural, which has antitumor effects. However, previous studies on the antitumor effects of garlic focused on other organosulfur compounds, such as diallyl disulfide (DADS) (Liao et al. 2009; Yin et al. 2018), DATS (Li \& Lu 2002), and ajoene (Li et al. 2002).

In this study, we found low levels of some sulfides in the garlic extracts that could still be noteworthy (Fig. 2\&3): 3-vinyl-1,2-dithiacyclohex-4-ene (0.98\% in 'Hongqixing', $0.16 \%$ in 'Ershuizao'), 3-vinyl-1,2-dithiacyclohex-5-ene (1.14\% in 'Taicangbaipi', 4.46\% in 'Hongqixing', $1.48 \%$ in 'Ershuizao'), and Diallyl trisulfide (DATS) $(0.74 \%$ in 'Taicangbaipi', $1.64 \%$ in 'Hongqixing', $0.38 \%$ in 'Single-clove'). Many studies have shown that garlic has an inhibitory effect on microorganisms (Curtis et al. 2004; Mirik \& Aysan 2005; Slusarenko et al. 2008), and the bacteriostatic effect of garlic is known to be related to its organic sulfur compounds (Cavallito et al. 1944; Oommen et al. 2004). The difference in the sizes of the inhibition zones in Fig. 4 may be associated with the presence of these sulfides. Many studies have shown that the composition of different species or varieties of plant extracts differs, and their inhibitory effects on bacteria also differ. Khammuang and Sarnthima reported differences in the antioxidant and antibacterial activities of four seed extracts from fresh Thai varieties of mango (Khammuang \& Sarnthima 2011). Smolskaitè studied the antibacterial properties of wild mushroom extracts, and found that the extract of Inonotus hispidus was more effective against Bacillus cereus, Pseudomonas aeruginosa, and Candida albicans than that of other mushrooms (Smolskaite et al. 2015).

The mechanism of how the garlic extracts kill microorganisms may be via the destruction of the bacterial plasma membrane. The observed changes in membrane conductivity and protein leakage indicate that the garlic extracts could destroy the structural integrity of the cell membranes of $X$. campestris pv. malvacearum (Fig. 5). Bacterial cell membranes provide conditions for the selective permeation of small ions such as $\mathrm{K}^{+}$and $\mathrm{Na}^{+}$(Harold \& Altendorf 1974; Lanyi 1979), and once the cell membrane is damaged, loss of cell contents can lead to cell death (Cui et al. 2015; Ming et al. 2008).

The garlic plant has a high value as a seasoning agent, and we found that the 'Hongqixing' and 'Ershuizao' varieties exhibit the best results in terms of their antimicrobial properties, 5Hydroxymethylfurfural production, and prominence of aromatic components. 'Hongqixing' and 'Ershuizao' are local garlic varieties, particular to the Sichuan Province of China; they are both 
253 quite famous for their strong aroma and storability. The present study has highlighted the value 254 of the 'Hongqixing' and 'Ershuizao' varieties. Considering all the positive characteristics of the 255 'Hongqixing' and 'Ershuizao' varieties, their production should be increased. Their antimicrobial 256 properties could potentially be used in agriculture, for example in organic farming, and their high 257 production of 5-Hydroxymethylfurfural could make them antioxidant health foods.

\section{5. Conclusions}

259 In this study, four varieties of garlic were compared with respect to their nutrients, their 260 levels of various compounds, antimicrobial and antitumor activity. Among these four varieties, 261 'Hongqixing' and 'Ershuizao' are unique to the Sichuan Province of China, and they are 262 distinctive. Thus, we suggest that 'Hongqixing' and 'Ershuizao' should be given more prominent 263 roles in agriculture and health foods. 
265

266

267

268

269

270

271

272

273

274

275

276

277

278

279

280

281

282

283

284

285

286

287

288

289

290

291

292

293

294

295

296

297

298

299

300

301

302

303

304

305

\section{References}

Cavallito CJ, Buck JS, and Suter CM. 1944. Allicin, the Antibacterial Principle of Allium sativum. II. Determination of the Chemical Structure. J Am Chem Soc 66:1952-1954.

Chen C, Liu CH, Cai J, Zhang W, Qi WL, Wang Z, Liu ZB, and Yang Y. 2017. Broad-spectrum antimicrobial activity, chemical composition and mechanism of action of garlic ( Allium sativum ) extracts. Food Control:117-125.

Cho SK, and Kim WT. 2008. Arabidopsis PUB22 and PUB23 Are Homologous U-Box E3 Ubiquitin Ligases That Play Combinatory Roles in Response to Drought Stress. Plant Cell 20:1899-1914.

Choi IS, Cha HS, and Lee YS. 2014. Physicochemical and antioxidant properties of black garlic. Molecules 19:1681116823.

Cui H, Zhao C, and Lin L. 2015. The specific antibacterial activity of liposome-encapsulated Clove oil and its application in tofu. Food Control 56:128-134.

Curtis H, Noll U, Störmann J, and Slusarenko AJ. 2004. Broad-spectrum activity of the volatile phytoanticipin allicin in extracts of garlic (Allium sativum L.) against plant pathogenic bacteria, fungi and Oomycetes. Physiological and Molecular Plant Pathology 65:79-89.

Diao WR, Hu QP, Zhang H, and Xu JG. 2014. Chemical composition, antibacterial activity and mechanism of action of essential oil from seeds of fennel ( Foeniculum vulgare Mill.). Food Control 35:109-116.

Ding X, Wang MY, Yao YX, Li GY, and Cai BC. 2010. Protective effect of 5-hydroxymethylfurfural derived from processed Fructus Corni on human hepatocyte LO2 injured by hydrogen peroxide and its mechanism. $J$ Ethnopharmacol 128:373-376.

Durak I, Aytaç B, Atmaca Y, Devrim E, Avcı A, Erol Ç, and Oral D. 2004. Effects of garlic extract consumption on plasma and erythrocyte antioxidant parameters in atherosclerotic patients. Life Sciences 75:1959-1966.

Harold FM, and Altendorf K. 1974. Cation Transport in Bacteria: K +, Na + , and H +. Current Topics in Membranes \& Transport 5:1-50.

Hosono T, Fukao T, Ogihara J, Ito Y, Shiba H, Seki T, and Ariga T. 2005. Diallyl trisulfide suppresses the proliferation and induces apoptosis of human colon cancer cells through oxidative modification of beta-tubulin. Journal of Biological Chemistry 280:41487-41493.

Hwang IG, Kim HY, Woo KS, Lee J, and Jeong HS. 2011. Biological activities of Maillard reaction products (MRPs) in a sugar - amino acid model system. Food Chem 126:221-227.

Irigoyen JJ, Einerich DW, and Sánchez - Díaz M. 1992. Water stress induced changes in concentrations of proline and total soluble sugars in nodulated alfalfa (Medicago sativd) plants. Physiologia Plantarum 84:55-60.

Itakura Y, Ichikawa M, Mori Y, Okino R, Udayama M, and Morita T. 2001. How to distinguish garlic from the other Allium vegetables. Journal of Nutrition 131:963S-967S.

Khammuang S, and Sarnthima R. 2011. Antioxidant and antibacterial activities of selected varieties of Thai mango seed extract. Pak J Pharm Sci 24:37-42.

Lanyi JK. 1979. The role of $\mathrm{Na}+$ in transport processes of bacterial membranes. Biochim Biophys Acta 559:377-397.

Li M, Ciu JR, Ye Y, Min JM, Zhang LH, Wang K, Gares M, Cros J, Wright M, and Leungtack J. 2002. Antitumor activity of Z-ajoene, a natural compound purified from garlic: antimitotic and microtubule-interaction properties. Carcinogenesis 23:573-579.

Li Y-X, Li Y, Qian Z, Kim M, and Kim S. 2009. In vitro antioxidant activity of 5-HMF isolated from marine red alga Laurencia undulata in free-radical-mediated oxidative systems. Journal of Microbiology \& Biotechnology 19:1319-1327. 
306

307

308

309

310

311

312

313

314

315

316

317

318

319

320

321

322

323

324

325

326

327

328

329

330

331

332

333

334

335

336

337

338

339

340

341

342

343

344

345

346

Li Y, and Lu YY. 2002. Isolation of diallyl trisulfide inducible differentially expressed genes in human gastric cancer cells by modified cDNA representational difference analysis. Dna \& Cell Biology 21:771-780.

Liao QJ, Su J, He J, Song Y, Tang HL, and Su Q. 2009. Effect of diallyl disulfide on cell cycle arrest of human colon cancer SW480 cells. Chinese Journal of Cancer 28:138-141.

Lu X, Li N, Qiao X, Qiu Z, and Liu P. 2017. Composition analysis and antioxidant properties of black garlic extract. Journal of Food \& Drug Analysis 25:340-349.

Martins N, Petropoulos S, and Ferreira IC. 2016. Chemical composition and bioactive compounds of garlic (Allium sativum L.) as affected by pre- and post-harvest conditions: A review. Food Chem 211:41-50.

Matsutomo T, Stark TD, and Hofmann T. 2018. Targeted screening and quantitative analyses of antioxidant compounds in aged-garlic extract. European Food Research \& Technology:1-12.

Michail K, Matzi V, Maier A, Herwig R, Greilberger J, Juan H, Kunert O, and Wintersteiger R. 2007. Hydroxymethylfurfural: an enemy or a friendly xenobiotic? A bioanalytical approach. Analytical \& Bioanalytical Chemistry 387:2801.

Ming K, Xi GC, Cheng SL, Chen GL, Xiang HM, and Le JY. 2008. Antibacterial mechanism of chitosan microspheres in a solid dispersing system against E. coli. Colloids \& Surfaces B Biointerfaces 65:197-202.

Mirik M, and Aysan Y. 2005. Effect of Some Plant Extracts as Seed Treatments on Bacterial Spot Disease of Tomato and Pepper.

Molina-Calle M, Priego-Capote F, and Castro MDLD. 2017. Headspace-GC-MS volatile profile of black garlic vs fresh garlic: Evolution along fermentation and behavior under heating. LWT - Food Science and Technology 80:98-105.

Monti LL, Bustamante CA, Osorio S, Gabilondo J, Borsani J, Lauxmann MA, Maulión E, Valentini G, Budde CO, and Fernie AR. 2016. Metabolic profiling of a range of peach fruit varieties reveals high metabolic diversity and commonalities and differences during ripening. Food Chem 190:879-888.

Mukthamba P, and Srinivasan K. 2015. Beneficial hypolipidemic influence of a combination of dietary fenugreek ( Trigonella foenum - graecum ) seeds and garlic (Allium sativum ) in induced hypercholesterolemic rats. European Food Research \& Technology 240:1049-1058.

Oommen S, Anto RJ, Srinivas G, and Karunagaran D. 2004. Allicin (from garlic) induces caspase-mediated apoptosis in cancer cells. European Journal of Pharmacology 485:97.

Ozturk M, Gucel S, Altay V, and Altundag E. 2012. ALLIUMS, AN UNDERUTILIZED GENETIC RESOURCE IN THE EAST MEDITERRANEAN. Acta Horticulturae 969:303-309.

Park GG, Park JJ, Yoon J, Yu SN, and An G. 2010. A RING finger E3 ligase gene, Oryza sativa Delayed Seed Germination 1 (OsDSG1), controls seed germination and stress responses in rice. Plant Molecular Biology 74:467.

Perez LC, and Yaylayan VA. 2008. Isotope labeling studies on the formation of 5-(hydroxymethyl)-2-furaldehyde (HMF) from sucrose by pyrolysis-GC/MS. J Agric Food Chem 56:6717-6723.

Sadasivam S, Manickam, A. 1997. Biochemical Methods. 2nd ed. New Age International, New Delhi.

Shang RF, Wang GH, Xu XM, Liu SJ, Zhang C, Yi YP, Liang JP, and Liu Y. 2014. Synthesis and biological evaluation of new pleuromutilin derivatives as antibacterial agents. Molecules 19:19050-19065.

Slusarenko AJ, Patel A, and Portz D. 2008. Control of plant diseases by natural products: Allicin from garlic as a case study. European Journal of Plant Pathology 121:313-322.

Smolskaite L, Venskutonis PR, and Talou T. 2015. Comprehensive evaluation of antioxidant and antimicrobial 
347

348

349

350

351

352

353

354

355

356

properties of different mushroom species. LWT - Food Science and Technology 60:462-471.

Steiner M, Khan AH, Holbert D, and Lin RI. 1996. A double-blind crossover study in moderately hypercholesterolemic men that compared the effect of aged garlic extract and placebo administration on blood lipids. American Journal of Clinical Nutrition 64:866-870.

Yin X, Feng C, Han L, Ma Y, Jiao Y, Wang J, Jia L, Jing F, Gao X, and Zhang Y. 2018. Diallyl disulfide inhibits the metastasis of type II esophageal-gastric junction adenocarcinoma cells via NF-KB and PI3K/AKT signaling pathways in vitro. Oncology Reports 39:784.

Zheng G, Zheng Z, Xu X, and Hu Z. 2010. Variation in fruit sugar composition of Lycium barbarum L. and Lycium chinense Mill. of different regions and varieties. Biochemical Systematics and Ecology 38:275-284. 


\section{Figure 1}

Four different varieties of garlic.

(A-D) Peeled garlic cloves; (E-H) Garlic bulbs.

(A, E) Taiczangbaipi.; (B, F) Hongqixing; (C, G) Ershuizao; (D, H) Single-clove.

*Note: Auto Gamma Correction was used for the image. This only affects the reviewing manuscript. See original source image if needed for review.

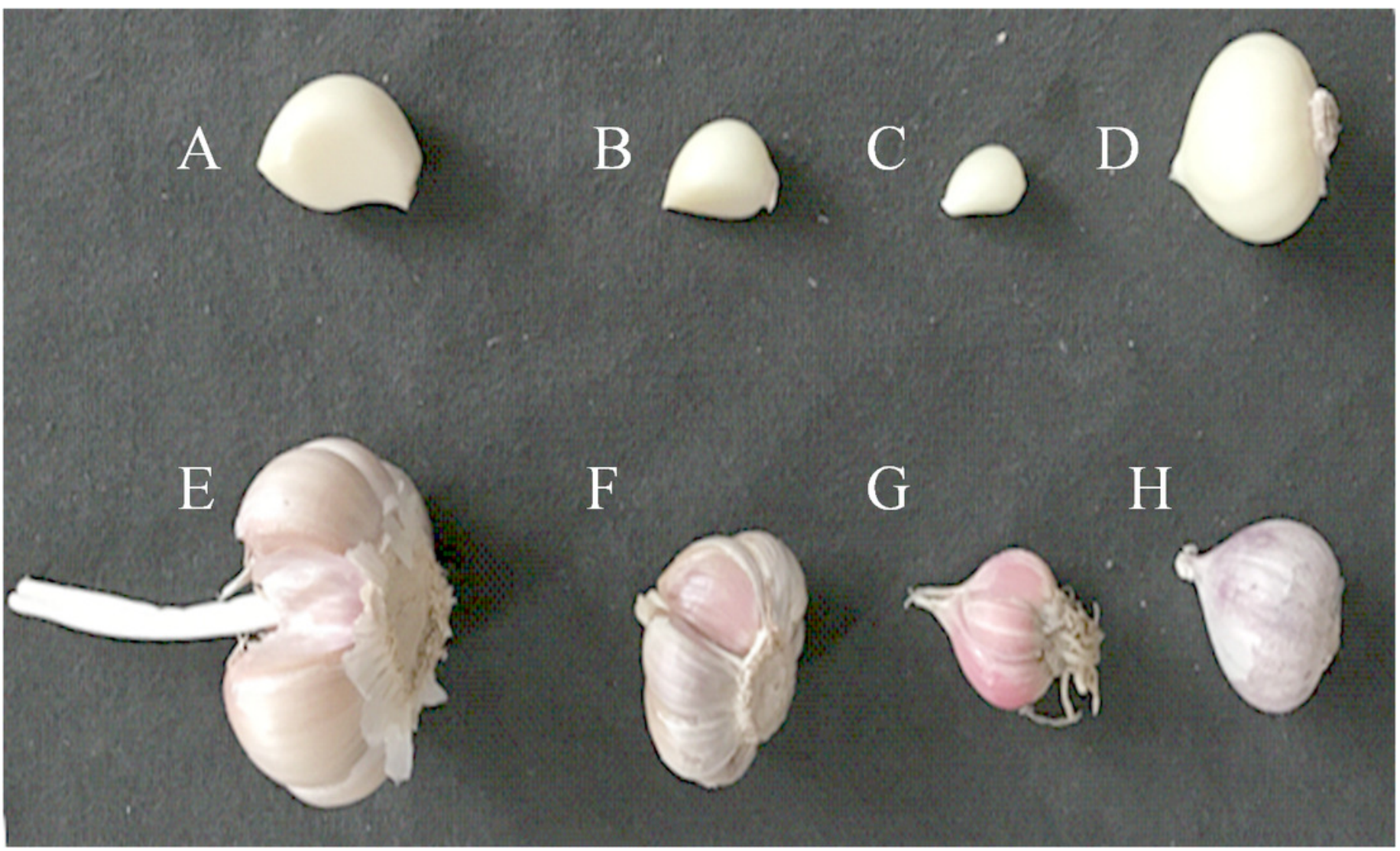


Figure 2

GC-MS spectra of the constituents of four different varieties of garlic.

(A) Taicangbaipi; (B) Hongqixing; (C) Ershuizao; (D) Single-clove.

Constituents: (1) Ethylic acid; (2)2-Amino-5-methylbenzoic acid; (3) 3-Vinyl-1,2-dithiacyclohex4-ene; (4) 3-Vinyl-1,2-dithiacyclohex-5-ene; (5) 5-Hydrxoymethylfurfural; (6) Diallyl trisulfide (DATS); (7) $\beta$-D-fructofuranosyl $\alpha$-D-glucopyranoside. 


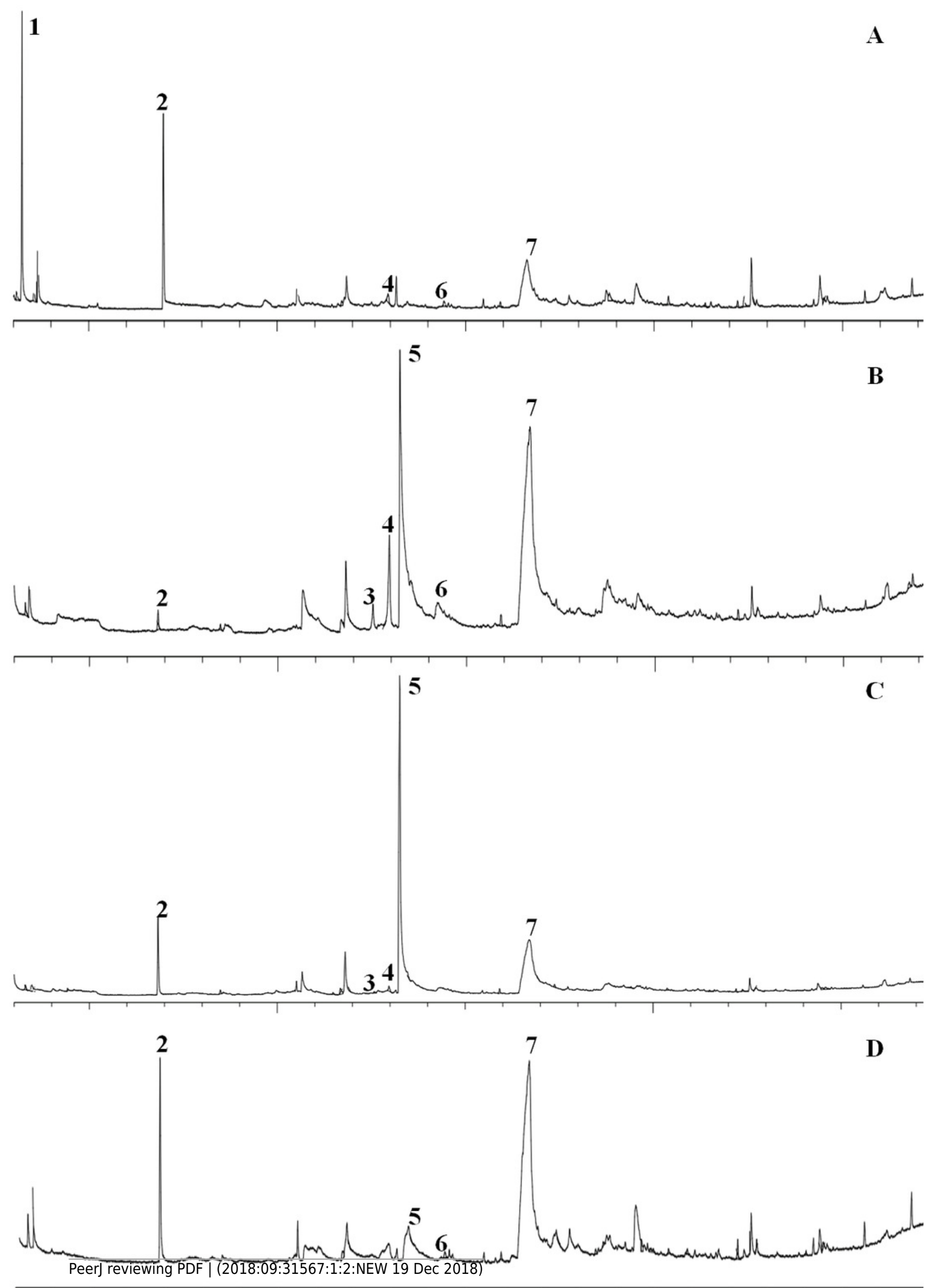




\section{Figure 3}

Mass spectra of major compounds.

Constituents: (A) Ethylic acid; (B)2-Amino-5-methylbenzoic acid; (C) 3-Vinyl-1,2-dithiacyclohex-4-ene; (D) 3Vinyl-1,2-dithiacyclohex-5-ene; (E) 5-Hydrxoymethylfurfural; (F) Diallyl trisulfide (DATS); (G) $\beta$-Dfructofuranosyl $\alpha$-D-glucopyranoside. 

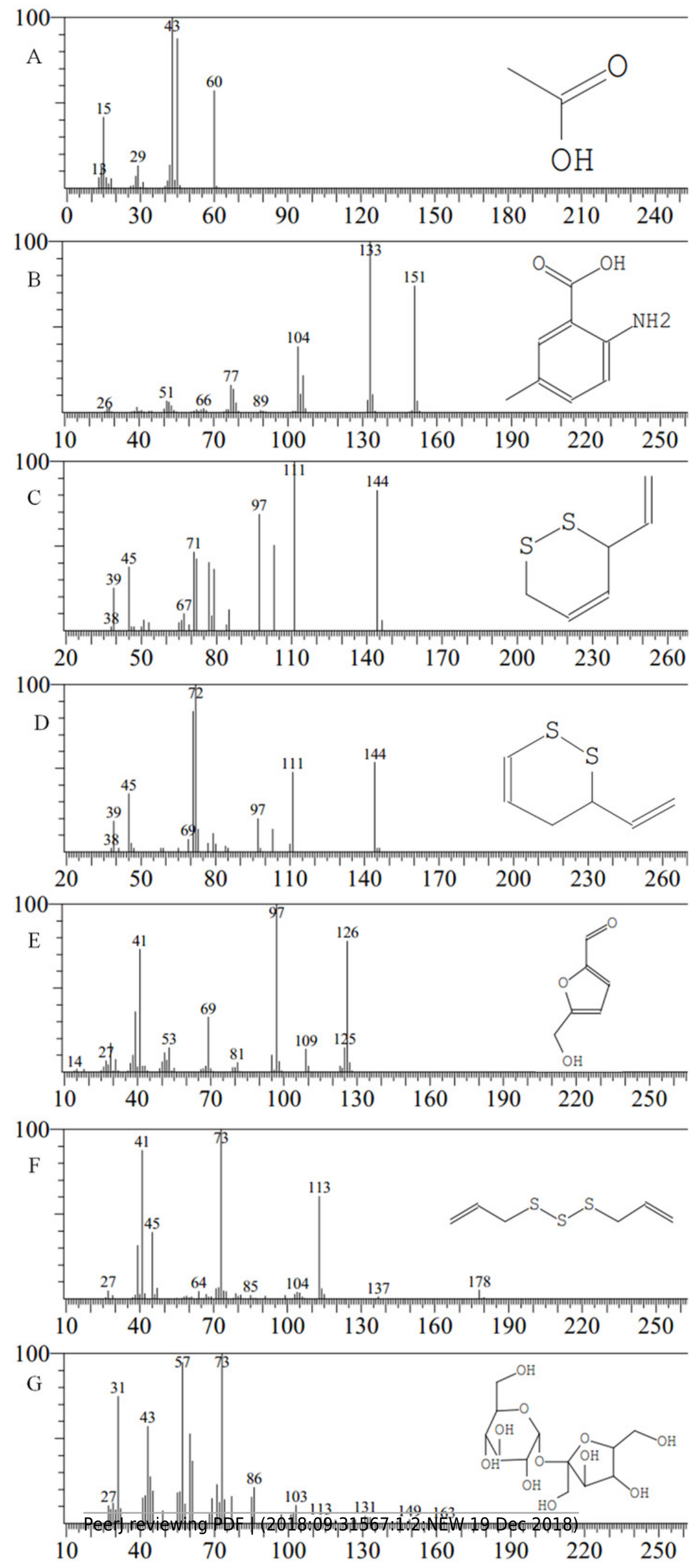


\section{Figure 4}

Zones of inhibition caused by the extracts of four varieties of garlic on seeded agar plates. Each cup had $20 \mu \mathrm{L}$ of garlic extract added to it.

(A) X. campestris pv. Malvacearum; (B) P. syringae; (C) F. proliferatum; (D) A. brassicicola. (i) Hongqixing; (ii) Ershuizao; (iii) Taicangbaipi; (iv) Single-clove . 

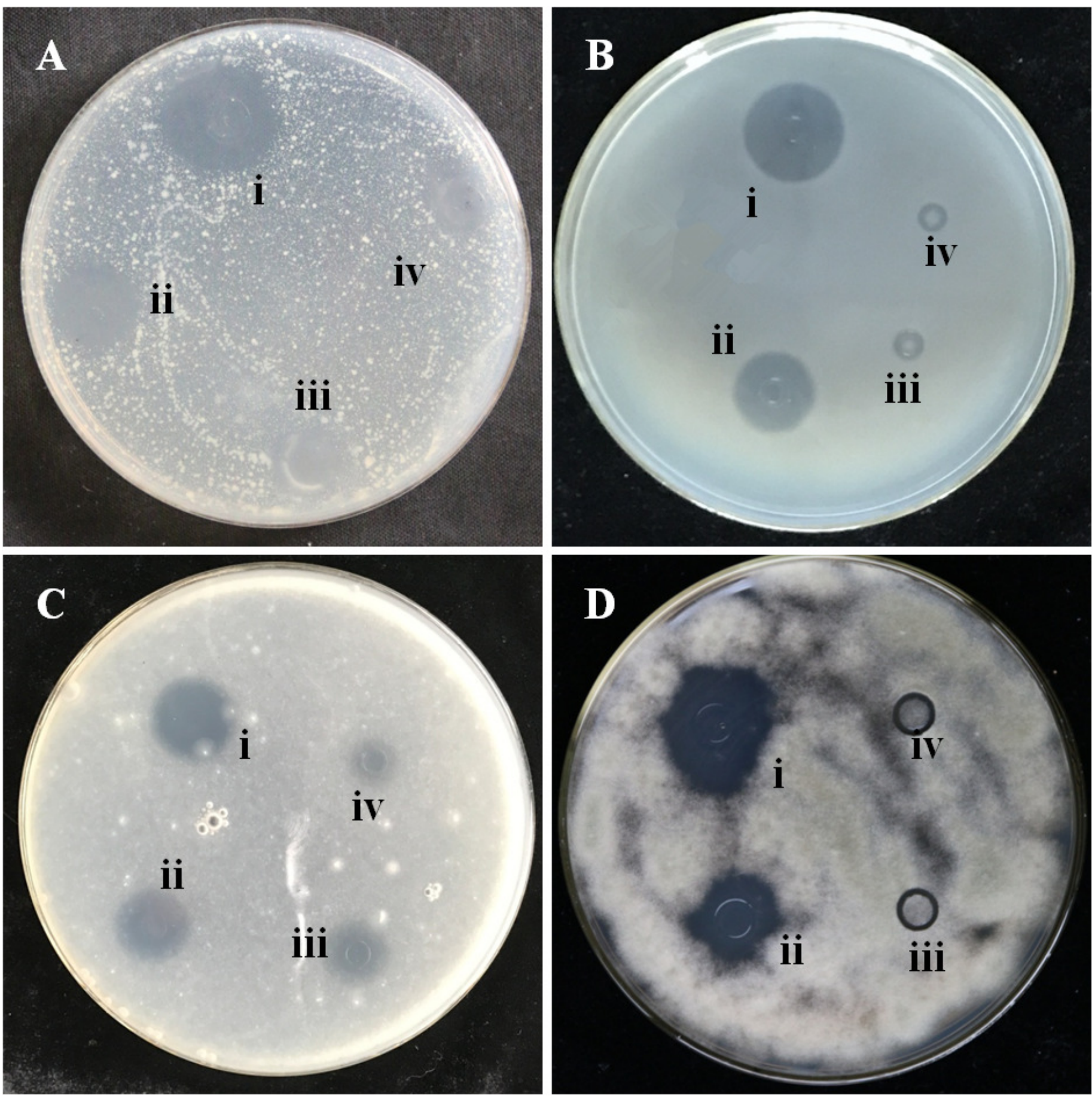


\section{Figure 5}

Effect of garlic extracts on the membrane permeability (A) and protein leakage (B) of $X$. campestris pv. malvacearum.

Values are means $\pm S D(n=3)$.

(C) Control; (T) Taicangbaipi; (S) Single-clove; (E) Ershuizao; (H) Hongqixing. 

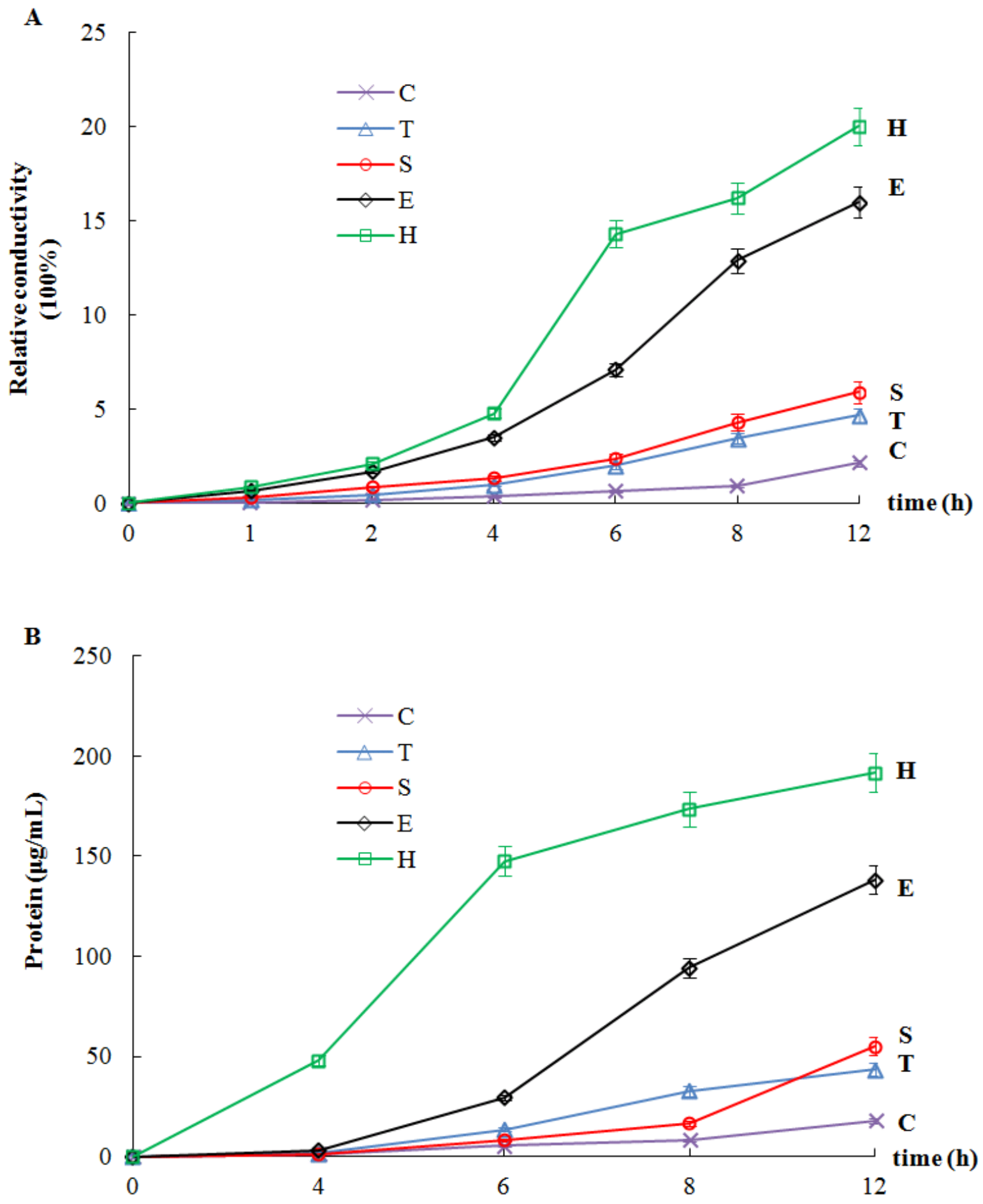
Figure 6

Analysis of cytotoxic effects on SW480 cells (A) and HCT116 cells (B).

Values are means \pm SD $(n=3)$.

(E) Ershuizao; (H) Hongqixing; (S) Single-clove; (T) Taicangbaipi.
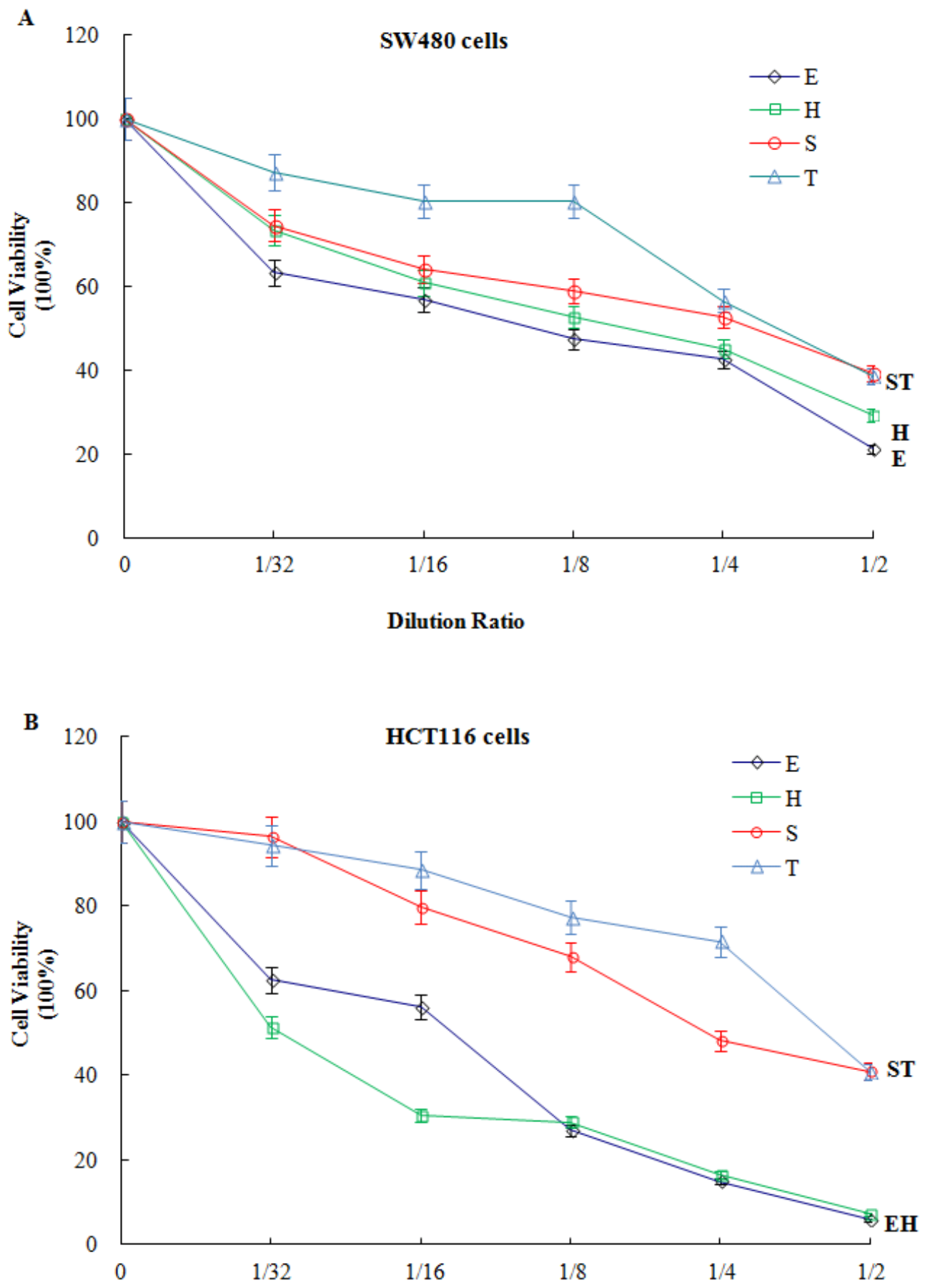


\section{Table $\mathbf{1}$ (on next page)}

Soluble sugar, total starch, and protein content in 'Taicangbaipi', 'Hongqixing', 'Ershuizao', and 'Single-clove' extracts.

*: Values represent the means of three independent replicates 
1 Table 1: Soluble sugar, total starch, and protein content in 'Taicangbaipi', 'Hongqixing', 'Ershuizao', 2 and 'Single-clove' extracts.

\begin{tabular}{lllllll}
3 & & & & & & $*:$ Values \\
4 & varieties of garlic & Soluble sugar $(\mathbf{m g} / \mathbf{g})$ & Total starch $(\mathbf{m g} / \mathbf{g})$ & Protein $(\mathbf{m g} / \mathbf{g})$ & represent \\
\cline { 2 - 5 } 5 & Taicangbaipi & $32.31 \pm 0.15^{*}$ & $163.51 \pm 0.41$ & $21.09 \pm 0.16$ & the means \\
6 & Hongqixing & $34.14 \pm 0.08$ & $287.71 \pm 0.46$ & $45.23 \pm 0.11$ & of three \\
7 & Ershuizao & $80.47 \pm 0.20$ & $263.98 \pm 0.33$ & $51.04 \pm 0.32$ & independe \\
8 & Single-clove & $186.91 \pm 0.45$ & $205.66 \pm 0.13$ & $40.36 \pm 0.25$ & $\mathbf{n t}$
\end{tabular}

\section{9 replicates}

10 
Table 2 (on next page)

Major composition of 'Taicangbaipi', 'Hongqixing' , 'Ershuizao' and 'Single-clove' 


\section{Table 2: Major composition of 'Taicangbaipi', 'Hongqixing', 'Ershuizao' and 'Single-clove'}

2

\begin{tabular}{|c|c|c|c|c|c|c|c|c|c|}
\hline \multirow[t]{2}{*}{ Compound name } & \multicolumn{2}{|c|}{ Taicangbaipi } & \multicolumn{2}{|c|}{ Hongqixing } & \multicolumn{2}{|c|}{ Ershuizao } & \multicolumn{2}{|c|}{ Single-clove } & \multirow{2}{*}{$\begin{array}{l}\text { Ret. } \\
\text { Index }\end{array}$} \\
\hline & R.Time & Area\% & R.Time & Area $\%$ & R.Time & Area\% & R.Time & Area\% & \\
\hline Ethylic acid & 3.086 & 22.40 & - & - & - & - & - & - & 576 \\
\hline Hydroxyacetone & 3.544 & 1.93 & 3.300 & 0.37 & 3.304 & 0.35 & 3.332 & 1.38 & 698 \\
\hline Dimethylethylene glycol & - & - & - & - & 4.424 & 0.19 & - & - & 743 \\
\hline 2-Amino-5-methylbenzoic acid & 6.982 & 17.05 & 6.817 & 0.59 & 6.831 & 5.96 & 6.846 & 9.07 & 1575 \\
\hline 2,4-Dihydroxy-2,5-dimethyl-3(2H)-furan-3-one & - & - & 8.472 & 0.16 & 8.491 & 0.28 & - & - & 1173 \\
\hline Larixic acid & - & - & 10.662 & 3.16 & 10.665 & 2.94 & - & - & 1063 \\
\hline Methyl 2 -oxohexanoate & - & - & - & - & 11.483 & 0.09 & - & - & 1020 \\
\hline Levulinic acid & 11.708 & 0.58 & 11.667 & 0.79 & 11.683 & 0.82 & 11.692 & 0.65 & 1011 \\
\hline 3,5-Dihydroxy-6-methyl-2,3-dihydro-4H-pyran-4-one & 11.840 & 3.94 & 11.800 & 3.31 & 11.808 & 4.16 & 11.818 & 2.91 & 1269 \\
\hline 3-Vinyl-1,2-dithiacyclohex-4-ene & - & - & 12.520 & 0.98 & 12.583 & 0.16 & - & - & 1134 \\
\hline 3-Vinyl-1,2-dithiacyclohex-5-ene & 12.943 & 1.14 & 12.954 & 4.46 & 12.974 & 1.48 & - & - & 1134 \\
\hline 5-Hydrxoymethylfurfural & - & - & 13.234 & 26.78 & 13.261 & 47.10 & 13.456 & 4.88 & 1163 \\
\hline Acetoglyceride & - & - & 13.550 & 3.49 & - & - & - & - & 1091 \\
\hline Diallyl trisulfide (DATS) & 14.426 & 0.74 & 14.422 & 1.64 & - & - & 14.421 & 0.38 & 1350 \\
\hline Dodecanal & 15.923 & 0.37 & 15.915 & 0.36 & 15.918 & 0.37 & 15.922 & 0.29 & 1402 \\
\hline$\beta$-D-fructofuranosyl $\alpha$-D-glucopyranoside & 16.626 & 27.34 & 16.686 & 44.81 & 16.702 & 31.00 & 16.674 & 61.07 & 1444 \\
\hline Cyclododecane & 16.825 & 2.36 & - & - & - & - & 16.817 & 1.97 & 1439 \\
\hline 3,5-Di-tert-butylphenol & - & - & - & - & 17.381 & 0.21 & 17.386 & 1.65 & 1555 \\
\hline Hexadecane & - & - & - & - & - & - & 18.434 & 0.24 & 1612 \\
\hline 3-Deoxy-d-mannoic lactone & - & - & 18.642 & 1.86 & & & 18.633 & 0.22 & 1625 \\
\hline 1,3-Dimethylbarbituric acid & - & - & 18.741 & 2.01 & - & - & - & - & 1532 \\
\hline 3, 6-Diisobutyl-2, 5-piperazinedione & 18.825 & 1.41 & 18.808 & 1.11 & - & - & - & - & 1636 \\
\hline $\begin{array}{l}\text { Carbamic acid, N-methyl-N-[6-iodo-9-oxabicyclo } \\
\text { [3.3.1]nonan-2-yl]-, ethyl ester }\end{array}$ & - & - & 18.917 & 0.23 & - & - & - & - & 1922 \\
\hline 1-Alanine, N-butoxycarbonyl-, isobutyl ester & 19.528 & 5.05 & 19.548 & 1.44 & 19.413 & 0.11 & 19.502 & 7.20 & 1619 \\
\hline 8 -Methylheptadecan & - & - & - & - & - & - & 19.667 & 0.60 & 1746 \\
\hline Methyl 9-methylheptadecanoate & - & - & - & - & - & - & 19.975 & 0.43 & 2013 \\
\hline Tetradecanoic acid & 20.381 & 0.84 & - & - & 20.374 & 0.19 & 20.376 & 0.17 & 1769 \\
\hline
\end{tabular}




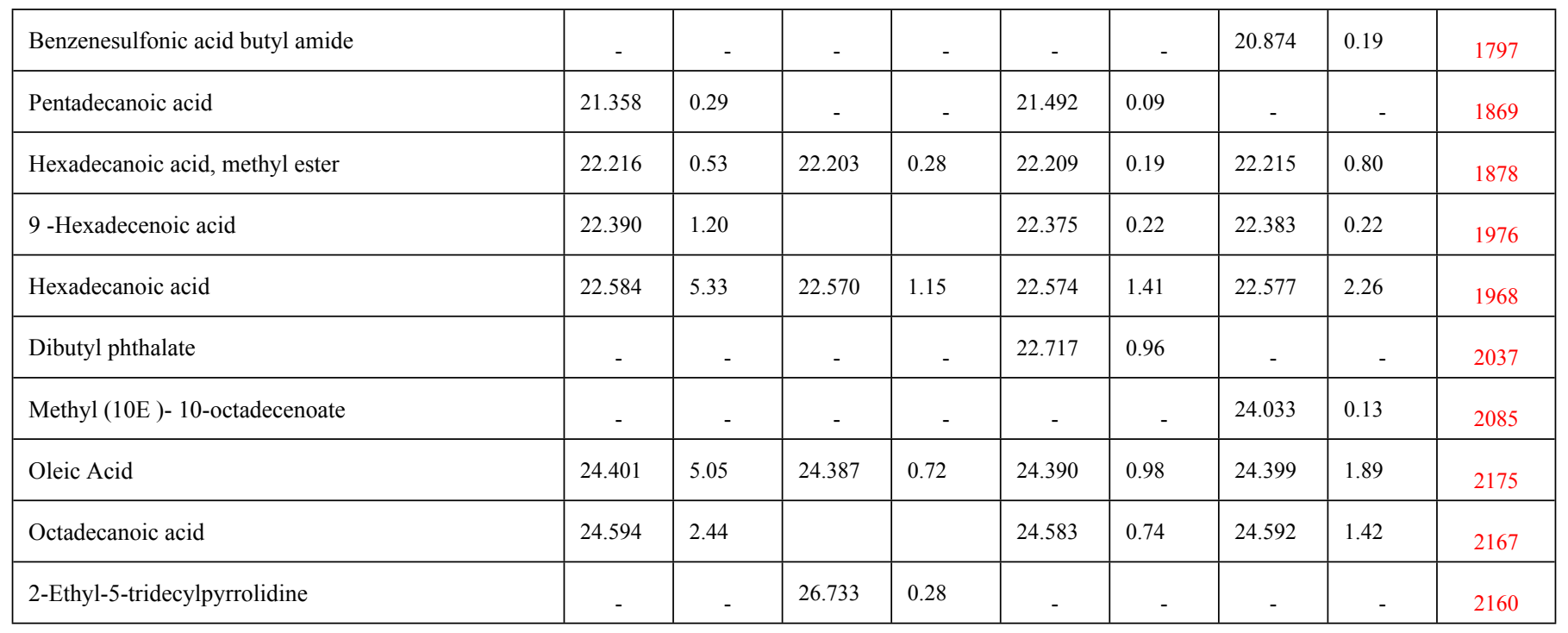

3 